\title{
Names for Characters in Russian Literature
}

\author{
JOHN P. PAULS
}

Thou art Simon, the son of Jonas: thou shalt be called Cephas [Peter], which is by interpretation, a stone.

John 1, 42

$\mathrm{H}$ ERE THE Gospel gives us a clear example of how a descriptive name ${ }^{1}$ originates. Jesus, upon seeing the strong belief of his disciple, Simon, renamed him "Cephas" or "Peter," because his faith was as strong as a rock, or a stone. This is probably the manner in which all names describing significant or dominant character traits of a person originated - names which constitute many first names and surnames in every language. An author does this very same thing when he ascribes a meaningful name to his character. One can find meaningful descriptive names in the literature of every country. In Beowulf, e.g., the name of the legendary King Breca is explained as 'breaker (of rings)' or 'breaker (of the ranks of the enemy).'2 In Tristan und Isolde by Gottfried von Strassburg, the name Tristan means 'a sad one.' In the Eastern European old epic songs (byl'ina) a hero's name, Dobr'ynya, is derived from the Old Slavic dobr'yni 'goodness.' In Shakespeare's comedies, we find such names as Alice Shortcake, Kate Keepdown, Anthony Dull and Peter Simple, which undoubtedly were once nicknames, describing some physical feature or character trait of a person. ${ }^{3}$ In our time, Bernard Shaw has used

1 I use the term "descriptive names" to signify those names which, in my opinion, the writer used intentionally to reveal some spiritual or physical quality of his character, or, in some cases, to make the character appear more humorous to the reader by merely giving him a funny-sounding name. In this article I discuss primarily humorous names, as they are the most picturesque. However, some nonhumorous and descriptive names and a few allegorical names are included here because they are especially significant or interesting.

2 Malone, Kemp, "Royal Names in Old English Poetry," Names, Vol. I, No. 3, September, 1953, p. 155.

3 Kellogg, Allen B., "Nicknames and Nonce-names in Shakespeare's Comedies," Names, Vol. III, No. 1, March, 1955, p. 1. 
"humorous" names such as Jeff Smilash, which he explained as "a compound of the words smile and eyelash," etc.

Now, when we look for names descriptive of character in Russian literature, we find that different authors treated this problem in various ways; e.g., Pushkin, Lermontov, Turgenev, and Leo Tolstoy used names for their characters which are usually without any preconceived meaning and are taken from everyday life. True, these names have some meaning, but they have no reference to the physical features or personality of their bearers. On the other hand, Fonvisin, Griboyedov, Gogol, Nekrasov, Ostrovsky, Dostoyevsky, Chekhov and Zoshchenko quite often bestowed amusing descriptive names upon their characters, which were used as an important device in characterization. Such names occur most frequently in their comedies, although they can be found to a lesser extent in their dramas, novels and short stories as well. Some of the names were so appealing to readers, and so accurate in their description of different human vices, that they became common nouns, describing the negative traits of the Russian national character. Such is Goncharov's Obl'omov (1859), 'one who has lost his ground, a dejected person' (<oblom'at' 'to break, to chip off'), a name which became a popular term for Russian laziness, inactivity, or unruffled peace, so much so, that now Oblomov and oblomovism have become common household words throughout Russia, just as Tartuffe is in France, Pecksniff in England, and Babbitt in America. Gogol's Khlestak'ov 'whipsnapper, blusterer' became a common word to describe a bluffer; his brutal policeman, Derzhim'orda 'one who holds the trap,' and Chekhov's ex-sergeant Prishib'eyev 'one who hurts, or one who could make a cripple of another' are colloquial names for the totalitarian-type of policeman. Perhaps Gorky had that kind of policeman in mind when he wrote that in Russia "every police sergeant felt that he was Ivan the Terrible."5 A reader who does not understand the meaning of such names cannot fully enjoy the meaning of the Russian literary work. Therefore, I hope to be of some help in explaining here some of the most typical meaningful names, as they appear in Russian literature.

4 Weintraub, Stanley, "Humors' Names in Shaw's Prentice Novels," Names, Vol. V, No. 4, December, 1957, p. 222.

5 Gorky, M., Culture and the People, New York, International Publishers, 1939, p. 41 . 
In my English evaluation of the meaning of Russian names, I shall give the closest possible description of the character, trying to follow the author's intention, which, in my opinion, is expressed by the name itself and by the author's attitude toward his character throughout the whole work. Suffixes in descriptive names - taken from literature - represent only the pattern of Russian names, such as the following:-ov/-ova, -ev/-eva, -in/-ina; -oy/-aya; -ovich/-ovna, -evich/-evna (son, daughter or descendant of ...) and typical Ukrainian suffixes, - $u k,-y u k$, -enko (patronymics); -skiy (-sky)/-skaya (local, ethnic, occupational names); and others.* It seems to me that when Gogol named his character Khlestak'ov, he did not mean 'son, or descendant of a whipsnapper,' but rather (Mr.) Whipsnapper'; similarly Sobak'evich is not 'son or descendant of sob'aka 'dog,' (nor 'son of a bitch' as some translate it, because 'bitch' in Russian is $s^{\prime} u k a$; thus, this expression would be $s^{\prime} u k i n s^{\prime} y n$ ) as it would be explained in the case of a real person bearing the name, but simply 'dog, cunning, or even beastly,' the traits Gogol endowed his character with. (N. B.: The Eastern Slavs, perhaps under the influence of the Bible, do not look upon the dog as a "faithful friend," as for instance, the Germanic peoples do, but rather as a beast possessing cunning, negative qualities.)

The patterns of some humorous Russian names can no doubt be found in Western literatures as well. The first Russian comedy writers freely borrowed plots and ideas from such Western writers as Shakespeare, Sheridan, Calderon, Moliere, Dumont, Gresset, Holberg, Lessing and others, and possibly may have even borrowed names of characters (or at least their patterns) as well. Gogol was the first to succeed in the creation of typical Russian comic characters. But even Gogol's characters have many Southern traits for instance, the Ukrainian temperament ${ }^{6}$ - and some of his Russian names are derived from Ukrainian words.

At the end of the 18th century, some minor Russian writers tried desperately to improve Russian drama by imitating French authors and endeavored to transplant Moliere's tradition to Russia. An important guiding influence was provided by the Empress Catherine II (reigned 1762-1796), who was in constant communication with

* See my article: "Surnames of Soviet Russian and other Communist Celebrities," Names, Vol. VIII, No. 4, Dec., 1960, pp. 220-239.

6 Pypin, A. N., Istoriya Russkoy Literatury, Vol IV, St. Petersburg, 1909, p. 483. 
Diderot, Voltaire, and others, and created a favorable atmosphere for literature and the theater at the imperial court. She herself wrote some acceptable comedies. Although a German princess by birth, she learned the Russian language so well that she created many popular and humorous types in Western style, especially of women characters with appropriate humorous names such as V'estnikova 'talebearer,' Vorch'alkina 'grumbler,' Chud'ikhina 'marvel,' Khanzh'akhina 'hypocrite,' and also some men characters: Molokos'osov 'milksop,' Rastoch'itel' 'spendthrift,' Dr'emov 'slumber'; a poverty-stricken fellow possessed by schemes for making money, Nekop'eykov 'nota-penny'; a bad poet, Stikhotk'achev 'verseweaver'; etc.?

But the first good comedy in Russia was written by D. I. Fonvisin (1745-1792), entitled $N^{\prime}$ edorosl' (1782), translated into English as The Minor, The Unlicked Cub or The Young Hopeful. The theme was concerned with the need for education in Russia. In this comedy, the names of some of the characters described their personalities; e.g., (Mrs.) Prostak'ova 'uncouth,' (Mr.) Starod'um 'oldthinker,' Pr'avdin 'truthful,' and Skot'inin 'beastly.' The private tutors were Vr'alman 'fibber,' Ts'iferkin 'cipher,' and Kut'eykin 'spree.'

An excellent satirical comedy on Moscow manners written by A, S. Griboy'edov (1795-1829), G'ore ot um'a (1823) (in English, The Misfortune of Being Clever), stirred up the wrath of society by its fearless exposure of some of its foibles. The main character, $C h^{\prime}$ atsky, representing the intelligentsia, has much in common with Alceste in Moliere's Misanthrope. However, the name Ch'atsky suggests only some obscure place. The representatives of backward tradition are $F^{\prime}$ amusov, possibly an abbreviated form of Latin famulus 'servile, or slave' of the abusive tradition; Repet'ilov 'prattler,' Molch'alin 'still'; and Skaloz'ub 'sneerer,' a stupid army officer.

It was only Nikolai Vasil'yevich Gogol-Yanovsky (1809-1852), who called to life the real Russian humorous type, created by his originality and skill in grotesque imagery. A son of the sunny Ukraine, Gogol, was inwardly very unhappy and of a complex nature; and yet it was he who brought humor, brilliancy; and imagination into Russian literature, expecially with his unpretentious novels

7 Coleman, A. F., Humor in the Russian Comedy from Catherine to Gogol, New York, Columbia University Press, 1925, p. $5 \mathrm{ff}$. 
mirroring the picturesque and colorful life in Ukrainian villages. Of Gogol's stories, Evenings on a Farm Near Dikanka (1831), Pushkin enthusiastically wrote: "Here is a real gaiety, sincere, not exaggerated, without artifice, without stiffness... How surprised we were by this Russian book, which forced us to laugh, we, who had not laughed since the times of Fonvisin!"s

In explaining Gogol's literary types and their names (which incidentally are a delight to the onomast), I shall divide them into two groups:

1. Those which occur in his Ukrainian and Petersburg novels, the grotesque, comic types with everyday names of a humorous nature.

2. Those from Reviz'or (The Inspector General) and Dead Souls, the caricature personalities with invented names primarily symbolizing individual vices.

\section{First group:}

In the Ukrainian novels, Gogol's personalities are gay, romantic, and heroic. They are real people from all walks of life: peasants, Cossacks, Ukrainian rustic gentry with simple, funny names, and typical amusing Ukrainian nicknames full of unsophisticated humor and good-natured sarcasm. Gogol did not invent these names, but he had heard them in his homeland, the Ukraine. ${ }^{9}$ And yet, he was able, as V. G. Belinsky - Russia's most articulate critic - said, to picture "the whole world with just one word."10 Here we find a young, poor but courageous lad, Holop'upenko 'Mr. Naked-navel' planning to marry the daughter of a rich, shrewd peasant, Cherev'yk 'Mr. Shoe'; then a Cossack, Tsyb'ula 'Mr. Onion,' or a village mayor, Makoh'onenko 'Mr. Poppy-grinder-stick.' Just as grotesque as the figures in Repin's painting, The Cossacks Writing a Letter to the Sultan (1880), are the names Gogol ascribed to his Cossacks: for instance, Chub 'tuft,' Sverbyh'uz 'itching buttocks,' Vertykhv'ist 'twiddling tail,' Bor'odavka 'wart,' $B^{\prime} u l$ 'ba 'potato,' (probably referring to the potato-shaped nose which is so frequently found among

${ }^{8}$ N. V. Gogol' v russkoy kritike. ., Moscow, Gosizdat, 1959, p. $41 \mathrm{ff}$.

9 Cf. Tupikov, N.M., Slovar' drevnerusskikh lichnykh sobstvennykh imen, St. Petersburg, 1903.

${ }^{10}$ N. V. Gogol', op. cit., p. 62. 
Ukrainian peasants) Sh'ylo 'awl,' Holod'ukha 'starving,' Kolop'er 'pushing wheel,' Nash 'ours,' Pal'yvoda 'madcap, one who tries to burn water,' Pokot'yp'ole 'tumbleweed' (which rolls over the field), Vovt'uzenko 'scrambler,' Holokop'ytenko 'naked hoof,' Tovstopy'at 'thick heel,' Horob'ets 'sparrow,' Zakrut'yhuba 'twisted lip,' etc.

His rustic gentlemen were Tovstoh' $u b$ 'thick lip,' $K^{\prime}$ urochka 'little chicken,' Storch'enko 'little stem,' and Shp'on'ka 'shirt-stud.' Two comic country squires were Dovhochkh'un 'Mr. Long-sneezer,' and Perer'epenko 'Mr. Crack.' These two gentlemen ruined themselves in endless lawsuits over an offensive word, "gander." And Gogol finished this hilarious story with this observation: "It is dreary to live in this world, gentlemen."

Gogol's Russian stories from Petersburg are also grotesque and some are fantastic, but the Russian names are more prosaic; e.g., a young officer, Pirog'ov 'pie,' and a schizophrenic artist, Piskary'ov 'gudgeon.' The government officials were Kovaly'ov 'smith' (from Ukr. kov'al' 'smith,' Russ. kuzn'ets), Bashm'achkin 'little shoe,' the artist Chartk'ov 'a little devil,' and a Russian teacher, Deyeprich'astiye 'participle.'

\section{Second group:}

Gogol's greatest comedy, Reviz'or (1836), is his strongest satire of beaurocratic Russia, where there are no sympathetic characters, but only caricatures of vulgarity and petty vices. The names here are appropriate for the grotesque characters: the young arch-bluffer from Petersburg, who was mistaken for the "inspector general," Khlestak'ov 'whipsnapper, blusterer' (< khlest'at' 'to whip, to snap'); the mayor, Skv'oznik-Dmukhan'ovsky 'see-through-everything, blower' ( $<$ skvoz' it 'to see through' and Ukr. $d m^{\prime}$ 'ukhaty 'to blow, to puff'); the superintendent of schools, Khl'opov 'slapper' (<khl'opat' 'to slap'); Judge Ly'apkin-Ty'apkin 'blurter' (<ly'apat'-ty'apat' 'to blurt out,' vulg.); the supervisor of charities, Zemlyan'ika 'strawberry'; an ardent reader of other people's letters, postmaster Shpy'okin 'spy' (< shpëk \| shpik, colloq. 'spy'); the retired officials Lyulyuk'ov 'rocker of babies,' Rastak'ovsky 'yes-man,' (incidentally a character type also found in America), and Kor'obkin 'box'; police captain Ukhov'ertov 'earwiggler'; policemen: Svistun'ov 'whistler,' $P^{\prime}$ ugovitsyn 'button,' Derzhim'orda 'hold-your-trap'; the merchant 
Abd'ulin - a Tartar name, but the Russian homonym to it is 'cheater' (<obd'ut' 'to cheat,' colloq.); and the wife of a locksmith (Mrs.) Poshly'opkina, 'oftenslapped.'*

Gogol's masterpiece is the novel, Dead Souls (first part, 1842), where his unsurpassed imagination created the most vivid and grotesque caricatures of the Russian province. Here he portrayed different types of heartless landowners, who were the masters of serfs. Gogol surveyed the situation, as he said, "with the laughter which is visible to the world, and with the tears, which are invisible." His main hero, who travels about Russia and buys up "dead souls," deceased serfs, is $C h^{\prime} i c h i k o v$, who is none other than a more mature and more sophisticated Khlestak'ov (see above).** He is not only an arch-bluffer but also a smoother talker than Khlestak'ov, cleverly and carefully promoting his own cause everywhere. He not only personifies a Russian swindler, but is "an immortal international type," as Prince P. A. Kropotkin thinks. ${ }^{11}$ Ch'ichikov's name means 'silver tongue, smooth talker, chirping like a bird,' and is derived from the Ukrainian dialectal chy-ch'ykaty 'to chirp.' The other types of landowners Gogol portrayed are a passive dreamer and charmer, Man'ilov 'allurer' ( $<$ man' it' 'to allure'); the beastly Sobak'evich 'a cunning one' ( $<$ sob'aka 'dog'); an arch-liar and cheater Nozdry'ov from nozdry'a 'nostril'; the antediluvian lady, Kor'obochka 'a little box'; the repulsive miser Ply'ushkin 'an ugly one' (cf. Ukr. ply'ushka, a dimin. of ply'uha 'a nasty, ugly woman' and the Russ. adj. plyug'avyi 'mean, shabby'); Pet'ukh 'rooster'; and the peasants Pr'obka 'cork,' Mil'ushkin 'darling,' etc.

Gogol's humorous characterization and grotesque imagery were unique in Russian literature and no other Russian writer compared with him in this respect, except perhaps - to some extent - Zosh-

* Here I would like to call attention to some inaccurate etymologies of Russian names in Masterpieces of the Russian Drama, ed. by G. R. Noyes, Vol. I, Dover Publ., New York, 1961, esp. on p. 158, where Khl'opov, Ly'apkin-Ty'apkin, Lyuluk'ov, Poshly'opkina, et. al., are erroneously translated as 'Bedbug, Bungle-Steal, Halloo, Draggletail,' instead of 'Slapper, Blurter, Rocker-of-babies, Oftenslapped...'

After writing my article, I received an interesting article on the typology of Slavic names: J. B. Rudnyćkyj, "Functions of Proper Names in Literary Work" in Stil- und Formprobleme in der Literatur, Heidelberg, 1959, pp. 378-383, where the reader will find a bibliography on the subject.

** See p. 11.

11 Kropotkin, P. A., Russian Literature: Ideals and Realities, London, Duckworth \& Company, 1916, p. 85. 
chenko. However, Gogol influenced quite a few writers, such as Ostrovsky, Dostoyevsky, Sukhovo-Kobylin, Bely and others.

In his dramas A. N. Ostrovsky (1823-1886) exposed the crudity of merchants, which Gogol had already satirized in his comedy, Marriage (1842). However, Ostrovsky's characters do not have Gogol's satiric humor, but rather a heavy realistic stamp of primitive wildness, which is even apparent in the names of his heroes, such as Dik'oy 'wild,' (Mrs.) Kab'anova 'boar,' Puz'atov 'fat belly,' Bry'ukhov 'protruded stomach,' Raznov'esov 'cheater on weights,' Gr'oznov 'dreadful,' $L^{\prime}$ 'upych 'skinner'; and T'igriy L'v'ovich Ly'utov < tigr 'tiger,' lev 'lion,' Ly'utyi 'fierce.' Some of the characters have sarcastically sweet names; e.g., Nezab'udkin 'forget-me-not,' Mil'ashin 'darling,' Dobrotv'orsky 'do gooder,' and Benevol'ensky 'benevolant.'

N. A. Nekrasov (1821-1878), the outstanding poet of the underdog, made original use of allegorical place-names to express the suffering of the Russian peasantry. In his satirical poem, Who Is Happy in Russia? (1863-1877), seven peasants were looking in vain for -Neporotaya gubernya 'unbeaten state,' Nepotroshchy'onaya v'olost' 'unbroken county' and $I z b^{\prime} y t k o v o$ sel'o 'village of plenty.' They were from such places as Podty'anuta 'tied up,' Terpig'orevo 'havepatience-in-grief,' Pustopor'ozhnyaya 'completely empty,' Zapl'atova 'pay for everything,' Dyry'avina 'full of holes,' Raz'utovo 'no shoes,' Znob'ishino 'always cold,' Gor'elovo 'burning village,' Ney'elovo 'starving,' and Neurozh'ayka 'barren soil.' The traveling peasants passed through such places as Isp'ugannaya 'fearful,' Podstr'elennaya 'wounded,' Bezgr'amotnaya 'illiterate,' B'osovo 'barefoot,' 'Adovshchina 'hell,' St'olbnyaki 'stump,' Dymogl'otova 'swallowing smoke' and Nag'otino 'naked'; but in spite of the fact that they never found a happy man, they were somehow optimistic about the future of the Russian people.

F. M. Dostoyevsky (1821-1881), the creator of the modern psychological novel, was not essentially a humorist and did not have the gaiety of Gogol. However, his first novels were written under the strong influence of Gogol's story, The Overcoat. Not only are there similar problems and characters in Dostoyevsky's first novels, but even the names he uses are reminiscent of Gogol. Here are some of Dostoyevsky's early characters: $D^{\prime}$ evushkin 'girl-boy,' (Miss) Dobros'elova 'from-a-good-village,' Prokh'archin 'food waster,' Polz'unk'ov 
'one who crawls,' $N$ 'etochka Nezv' anova 'non-existent-unnamed,' the writer Kor'ovkin 'little cow,' the clowns, Yezhev'ikin 'black raspberry' and $O p^{\prime}$ iskin 'a spelling error.'

There are many humorous situations and characters in Dostoyevsky's writings, even in Memoirs from the House of Death (1862), but he did not use meaningful names in it. In Crime and Punishment (1866), Marmel'adov 'Mr. Marmalade' was intended to be a clown, and was called $z a b^{\prime}$ 'avnik 'jester' by the people in the restaurant. Yet, with further development in the novel he became the most tragic character. Similarly, the saintly Prince $M^{\prime} y$ shkin 'little-mouse' in The Idiot (1868) and the weak-minded Smerdy'ak'ov 'stinker, serf' in The Brothers Karam'azov (1880) were originally intended to be comic figures, ${ }^{12}$ but they too became tragic figures in the course of the novels. Dostoyevsky's most significant names are Rask'olnikov 'dissenter, or one who has a split personality' and his antipode Razum'ikhin 'mind' ( $<r^{\prime}$ azum 'intellect, mind') Lebezy'ainikov 'submissive flatterer' ( $<$ lebez' it' 'to fawn'), and the selfish beast of prey, L'uzhin 'puddle' in Crime and Punishment.

A. P. Chekhov's works abound in humor, sympathy for his hero, and sad smiles. He created a multitude of characters from the frustrated common man. He bestowed some of them with meaningful names, such as Prishib'eyev 'one who hurts,' the retired army sergeant and self-styled village mayor whose name became a common swear word in Russia. Others, like the slavish official, Chervyak'ov 'worm,' were the greedy peasant Tsyb'ukin 'pipestem'; the selfish, unsociable physician, St'artsev 'ancient'; the clever and greedy businessman of the peasants, Lop'akhin 'big spade'; the landowners who were gradually becoming a disappearing class, Mme. Ran'evskaya 'former,' and her brother, $G^{\prime}$ ayev 'grove.' But, for the onomast, the most interesting story in Russian literature may very well be Chekhov's The Horsey Surname, where the clerk, having forgotten the name of $O v s^{\prime} o v<o v ' e ̈ s$ 'oat,' in his desperate attempt to recall it, composed 38 new surnames derived from horses or objects connected with horses.

M. M. Zoshchenko (1895-1958), a Soviet humorist and satirist of Ukrainian origin, skillfully ridiculed the drabness of Soviet reality,

12 Zaslavsky, D. O., "Zametki o yumore i satire $\mathrm{v}$ proizvedeniyakh Dostoevskogo," Tvorchestvo Dostoevskogo, Moscow, Akademiya Nauk SSSR, 1959, pp. 444-71. 
until he was purged in 1946 by A. Zhdanov and expelled from the Writer's Union. His hilarious stories abound in humorous names like that of the teacher Tr'upikov 'little corpse,' who is afraid of his progressive Soviet pupils (1918), such as $S^{\prime}$ emechkin 'little seed,' who censored him severely. Then there are the peasant poet Ovch'innikov 'sheep shearer' and other Soviet citizens, such as $K^{\prime} u c h k i n$ 'pile,' Bl'okhin 'flea,' B'abkin 'grandma's boy,' Zh'ukov 'beetle,' Kl'opov 'bedbug,' G' usev 'goose,' M'ukhin 'fly,' Chesn'ok'ov 'garlic,' Gorb'ushkin 'a little hunchback,' Koson'osov 'crooked nose,' and (Mrs.) $B^{\prime}$ ykina 'ox,' etc.

The names of characters discussed here are the most widely known ones, generally understood by educated Russians, and can be regarded as the most typical ones in Russian literature. My treatment of the subject here, however, can hardly be regarded as exhaustive. Yet, I hope these few remarks will give the American reader some insight into the meaning of names used by Russian writers, and thereby enable him to better understand and more fully appreciate Russian literature.

University of Cincinnati 